\title{
TRENDS KRIMINAL DI PEKANBARU 2012-2016
}

\author{
Dr. Syahrul Akmal Latief, M.Si., Fakhri Usmita, M.Krim \\ \& Riky Novarizal, M.Krim
}

\begin{abstract}
The least availability of criminal data for the community, makes it difficult to get a picture of the crime. This study aims to illustrate the trend of crime in Pekanbaru City in 2012-2016 by using a quantitative alignment in view of police criminal statistics in Pekanbaru. This study focuses on eight criminal acts, namely: theft of two-wheeled vehicles, theft by weight, maltreatment, narcotics abuse, embezzlement, domestic violence, motor vehicle theft, and deprivation. The results of this study indicate a fluctuation of crime rates for eight crimes under investigation. The crime total reached in 2014 was 928 cases, and relatively decreased for the following years. The average trend of increasing or decreasing crime amounted to 19.5 cases per year.
\end{abstract}

Keywords: trend criminal, statistic criminal

\section{Pendahuluan}

Peristiwa kejahatan terjadi hampir setiap saat, diantara kejahatan yang terjadi tidak jarang menarik perhatian masyarakat, dan media. Tidak dapat dipungkiri, perkembangan sosial telah membawa pada berkembangnya permasalahan sosial. Urbanisasi yang seakan tidak terkendali membawa pada berkembangnya pusat-pusat kota baru, namun di sisi lain, keterbatasan sarana dan prasarana pendukung telah “memaksa” sebagian anggota masyarakat untuk "membiasakan diri" hidup dalam konflik, bahkan ketakutan.

Di sisi lain, terdapat anggapan bahwa angka kejahatan (peristiwa kejahatan) dapat dijadikan sebagai indikasi kondisi dan tingkat kesejahteraan masyarakat suatu wilayah. Semakin tinggi perbandingan angka kejahatan (per 1000 penduduk) mengindikasikan tingkat kesejahteraan yang relative lebih buruk dibanding wilayah yang memiliki perbandingan angka kejahatan lebih rendah. Peristiwa kejahatan yang terjadi tidak jarang menimbulkan ketakutan, kepanikan, hingga penderitaan bagi masyarakat.

Penelitian tentang tren kejahatan tidak terlepas dari hasil informasi dan kinerja para penegak hukum, termasuk laporan media, instansi medis, pengamat, peneliti, dan masyarakat (Richards and 
Goldberger dalam Understanding Crime Trends, 2008; 2). Dalam jangka pendek, memahami tren kejahatan berguna untuk memprediksi kemungkinankemungkinan kejahatan dimasa datang hingga dapat dicegah terjadinya kejahatan. Sedangkan dalam jangka panjang, hal ini berguna dalam memprediksi keterkaitan terjadinya kejahatan dengan faktor lain, misalnya laju industrialisasi, urbanisasi, pelayanan publik, teknologi, dan lain sebagainya. Sehingga dapat disusun kebijakan kriminal yang tepat guna mengantisipasinya.

Untuk itu, diperlukan adanya suatu upaya pengumpulan data obyektif, dan dapat dipertanggungjawabkan guna menjebatani keterbatasan data yang ada, dan salah satunya melalui penyusunan statistik kriminal. Statistik kriminal seperti halnya statistik pada umumnya, merupakan "alat" untuk menjawab pertanyaan. Statistik memudahkan kita mengolah informasi yang banyak menjadi pernyataan yang lebih sederhana. Di sisi lain, statistik (kuantitatif) merupakan dasar generalisasi informasi dari suatu informasi yang khusus (terbatas).

Tren kejahatan sebenarnya gambaran umum dari fenomena sosial, dan peneliti kriminologi sudah seharusnya memberikannya. Hal ini penting untuk dilakukan agar peramalan atau penyusunan kebijakan kriminal yang ada tidak "terbang tanpa arah”. Penjelasan atas kejahatan yang telah terjadi menjadi penting karena dari sinilah diperolehnya informasi dan alasan yang akurat demi pencegahan dan kebijakan di masa datang. Untuk itu, penulis tertarik melakukan penelitian tentang tren kejahatan di Pekanbaru.

Pekanbaru sebagai kota yang berkembang dengan pesat, demikian pula dengan permasalahan sosial yang mengiringinya. Perkembangan permasalahan sosial yang tidak kalah pesat tersebut memerlukan analisa, penyelesaian, dan antisipasi yang tepat. Untuk itu diperlukan tersedianya data yang akurat. Di Indonesia, data-data tersebut umumnya berupa deretan angka atau statistik yang bersumber dari satu sumber yaitu catatan kepolisian, termasuk publikasi laporan Badan Pusat Statistik.

Ketersediaan data ini memiliki peran yang sangat penting, terutama bagi penyusunan perencanaan dan penataan kota, pembuatan kebijakan perkembangan kota, penyusunan konsep kualitas hidup, bahkan bagi kepolisian 
sendiri. Sementara untuk dapat melakukan peramalan yang kemudian dijadikan dasar penyusunan rencana, kita harus dapat melihat pola atau tren perkembangan kejahatan dari tahun ke tahun, selain unsur lokalitas dimana suatu kebijakan kriminal akan disusun.

Pertanyaan yang diajukan pada penelitian ini adalah: bagaimana gambaran tren perkembangan kejahatan di Pekanbaru dalam lima tahun terakhir (2012-2016)

\section{Tinjauan Pustaka}

Kejahatan adalah "kerikil dalam sepatu” bagi masyarakat yang menginginkan adanya ketentraman. Pada awalnya, kejahatan dianggap sebagai suatu fenomena spiritualisme, dimana kejahatan dianggap sebagai suatu perbuatan yang dilakukan oleh seseorang yang telah terkena bujukan setan (Santoso, dan Zulfa, 2011: 29). Perkembangan selanjutnya, beberapa pemikir berpendapat bahwa pada dasarnya manusia adalah makhluk yang memiliki kehendak bebas (free will), yaitu kemampuan untuk mempertimbangkan segala tindakan berdasarkan keinginannya (Santoso, dan Zulfa, 2011:21).
Pemikiran adanya kehendak bebas dibantah oleh Cesare Lombroso. Menurut Lombroso, kejahatan yang dilakukan merupakan manifestasi dari sifat hewani yang ada dalam gen manusia, dimana sifat itu diturunkan dari generasi sebelumnya, dan dapat muncul sewaktu-waktu (Santoso, dan Zulfa, 2011:23).

Pendapat bahwa kejahatan merupakan suatu faktor yang diwariskan dari orang tua kepada keturunannya melalui secara genetis dibantahkan oleh temuan bahwa ada anak hasil adopsi yang juga melakukan kejahatan seperti orang tua adopsinya. Bantahan ini dikemukakan oleh Maneuver. Maneuver telah melihat adanya faktor lingkungan yang mempengaruhi seseorang berbuat jahat. Pendapat ini diperkuat oleh Tarde, bahwa seseorang berbuat jahat karena adanya peniruan terhadap perilaku orang lain (Santoso, dan Zulfa, 2011:25). Perkembangan selanjutnya, kejahatan tidak lagi dilihat dari sisi individu, melainkan merupakan suatu permasalahan sosial, yang kemudian dikenal sebagai era kriminologis modern, dimana terdapat pengaruh sosial dalam terbentuknya suatu perilaku jahat. Bagi kalangan kriminolog, kejahatan merupakan suatu keniscayaan, 
yang tidak dapat dihindari keberadaanya dalam suatu komunitas. Anggapan bahwa kejahatan adalah suatu hal yang normal dalam masyarakat ini dikemukakan oleh Emile Durkheim (Darmawan, 2007: 7.2).

Menurut Durkheim, kejahatan memiliki fungsinya tersendiri bagi setiap masyarakat. Setidaknya ada dua fungsi kejahatan bagi masyarakat menurut Durkheim, yaitu kejahatan sebagai agen perubahan, dan sebagai sesuatu yang dapat mempersatukan masyarakat. Kejahatan sebagai agen perubahan diartikan bahwa kejahatan merupakan indikator bagi adanya perkembangan dalam suatu masyarakat. Kejahatan tidak akan terjadi dalam masyarakat yang stagnan, yang bertingkah laku dalam cara yang sama, dan akan setuju dengan seluruh prinsip sosial yang ada. Jadi, kejahatan merupakan suatu perbuatan yang akan membawa pada adanya perubahan dalam masyarakat. Selanjutnya kejahatan sebagai pemersatu masyarakat. Pendapat ini didasari oleh anggapan bahwa kejahatan adalah "penyakit sosial" sehingga warga masyarakat akan secara bersama-sama melakukan reaksi untuk mengevaluasi norma-norma sosial yang telah disepakati (Darmawan, 2007: 73).
Adanya pelanggaran terhadap norma-norma sosial merupakan tolak ukur suatu perbuatan dapat dikatakan sebagai suatu perbuatan jahat ataupun tidak. Walau definisi norma sosial dipandang secara berbeda oleh banyak kriminolog. Perbedaan pendapat tersebut setidaknya terlihat pada pemikiran Edwin H. Sutherland dan Thorsten Sellin.

Sutherland memandang norma sosial yang dimaksud adalah normanorma yang telah diformalkan secara tertulis. Ia membatasi kejahatan sebagai perbuatan yang melanggar UndangUndang, yaitu suatu norma-norma sosial yang telah bersifat formal, telah ada tolak ukur yang baku terhadap suatu perbuatan itu jahat atau tidak, suatu perbuatan jahat hanya apa yang telah diatur oleh Undang-Undang (Darmawan, 2007: 1.4).

Berbeda dengan Sutherland, Sellin berpendapat bahwa kriminologi harus diperluas dengan mempelajari "conduct norms" (norma-norma tingkah laku), yaitu norma-norma tingkah laku yang telah digariskan atau ditentukan oleh berbagai kelompok masyarakat di mana individu merupakan anggota daripadanya (Darmawan, 2007: 1.6). Pendapat Sellin ini didukung oleh 
Mannheim, bahwa tidak saja perbuatanperbuatan yang oleh penguasa dinyatakan dilarang, tetapi juga tingkah laku yang oleh masyarakat (kelompokkelompok masyarakat) dianggap tidak disukai, meskipun tingkah laku ini tidak dilarang ataupun belum dilarang oleh hukum pidana (Darmawan, 2007: 1.7).

Pandangan Sellin tersebut didasari pada pemahaman bahwa kejahatan adalah suatu perilaku yang diciptakan oleh masyarakat. Gejala yang dinamakan kejahatan pada dasarnya terjadi di dalam proses dimana ada interaksi sosial antara bagian-bagian dalam masyarakat yang memiliki kewenangan untuk melakukan perumusan tentang kejahatan dengan pihak-pihak yang melakukan kejahatan.

Pendapat yang mengedepankan definisi kejahatan berdasarkan normanorma yang hidup di tengah-tengah masyarakat ini dikenal sebagai aliran sosiologis (Santoso, dan Zulfa, 2011: 15), bahwa tingkah laku tersebut sering terjadi di masyarakat dan melanggar sentimen kolektif (Mustofa, 2007: 16).

Secara sosiologis, kejahatan diartikan sebagai pola tingkah laku yang dilakukan oleh individu-individu, atau sekelompok individu, maupun suatu organisasi dalam masyarakat yang (perbuatan tersebut) merugikan masyarakat. Beberapa tingkah laku tersebut melalui suatu proses politik oleh lembaga legislative dirumuskan secara yuridis sebagai pelanggaran hukum dan kepada pelakunya diberi sanksi pidana (Mustofa, 23).

Adapun Pelaku kejahatan adalah:

a) Orang yang melakukan kejahatan.

b) Orang yang turut melakukan kejahatan.

c) Orang yang menyuruh melakukan kejahatan.

d) Orang yang membujuk orang lain untuk melakukan kejahatan.

e) Orang yang membantu untuk melakukan kejahatan.

Meski kejahatan merupakan suatu perbuatan yang dapat dikenakan sanksi pidana, namun terkadang tidak semua tindakan tersebut peristiwa yang terjadi menjadi peristiwa pidana.Peristiwa pidana merupakan suatu peristiwa yang ditangani dalam system peradilan pidana. Peristiwa pidana diawali dengan peristiwa yang dilaporkan. Peristiwa yang dilaporkan ialah setiap peristiwa yang dilaporkan masyarakat pada Polri, atau peristiwa dimana pelakunya tertangkap tangan oleh kepolisian. Laporan masyarakat ini akan dicatat dan ditindak-lanjuti oleh Polri jika dikategorikan memiliki cukup bukti. 
Peristiwa yang diselesaikan oleh kepolisian, adalah :

a) Peristiwa yang berkas perkaranya sudah siap atau telah diserahkan kepada jaksa.

b) Dalam hal delik aduan, pengaduannya dicabut dalam tenggang waktu yangtelah ditentukan menurut undang-undang.

c) Peristiwa yang tidak termasuk kompetensi Kepolisian.

d) Peristiwa yang tersangkanya meninggal dunia.

e) Peristiwa yang telah kadaluwarsa.

\section{Statistik Kriminal}

Umumnya terdapat dua sumber data utama dalam penyusunan statistik kriminal, pertama: catatan kepolisian, data ini lebih mudah diperoleh, selalu tersedia (available), dan cenderung konsisten (dalam pencatatan). Sumber lainnya adalah survey berkala, terutama terhadap korban kejahatan dalam populasi yang lebih besar. Permasalahan umumnya muncul pada penentuan sampel, selain permasalahanpermasalahan lain yang muncul saat pelaksanaan survey, ditambah tingkat kepercayaan pada sumber data (reliability of data) terutama ketika dibandingkan satu dengan lainnya (Schneider and Kitchen, 2004: 29).
Penyusunan statistik kriminal bersumber dari catatan kejahatan pihak kepolisian umumnya berupa: indeks kejahatan, angka kejahatan, waktu kejahatan (crime clock), dan presentase penyelesaian perkara (crime clearance) (Kusumah, 1982; BPS, 2015).

a) Pengukuran Indeks Kejahatan (It)

Indeks kejahatan yaitu persentase kenaikan atau penurunan kejadian kejahatan selama setahun dibandingkan terhadap satu tahun tertentu (yang dijadikan tahun dasar). Adapun rumus menentukan indeks kejahatan adalah sebagai berikut:

$$
\mathrm{I}_{\mathrm{t}}=\frac{\text { Jumlah peristiwa kejahatan pada tahun } \mathrm{t}}{\text { Jumlah peristiwa kejahatan pada tahun } \mathrm{t}_{\mathrm{o}}} \times 100
$$

Keterangan:

$$
\begin{aligned}
\mathrm{t}_{\mathrm{o}} & =\text { tahun dasar } \\
\mathrm{t} & =\text { tahun } \mathrm{t}
\end{aligned}
$$

b) Angka kejahatan (crime rate)

Angka kejahatan (umumnya per 10.000 orang penduduk) dengan cara perhitungan jumlah peristiwa kejahatan yang dilaporkan selama setahun dibagi jumlah penduduk pada tahun tersebut dikalikan 10.000(Kusumah, 1982: 46). Adapun rumus indeks kejahatan adalah sebagai berikut:

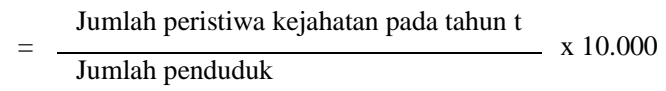


c) Skala waktu kejahatan/ tahun (crime clock)

$$
=\frac{365 \text { (hari) } \times 24 \text { (jam) } \times 60 \text { (menit) }}{\text { Jumlah peristiwa kejahatan tahun } \mathrm{t}} \times \text { detik }
$$

\section{Metode Penelitian}

Penelitian ini menggunakan metode ekonometrik, yaitu penggambaran ratarataangka kejahatan berdasarkan laporan yang diterima oleh pihak kepolisian (administrative based data).Pengolahan data penelitian ini menggunakan statistik deskriptif, dimana diharapkan dapat menarik simpulan dari informasi yang ada. Penelitian ini difokuskan pada hasil laporan kepolisian (statistik kriminal kepolisian) di kota Pekanbaru dengan tidak mengenyampingkan faktor-faktor lain seperti jumlah personil polisi, patroli rutin oleh polisi, fokus oprasi kepolisian, kondisi ekonomi masyarakat, angka pengangguran, urbanisasi, dan lain sebagainya.

\section{Jenis dan Sumber Data}

Jenis data pada penelitian ini yaitu data primer dan data skunder. Data utama (data primer) dikumpulkan dengan pencatatan data kriminalitas yang dimiliki oleh kepolisian di wilayah hukum kota Pekanbaru. Data kriminalitas ini hanya mencakup seluruh peristiwa atau kejadian kriminalitas yang dilaporkan oleh masyarakat, atau aksi kriminalitas yang pelakunya tertangkap tangan oleh kepolisian. Mengingat kemungkinan masih tingginya keengganan masyarakat untuk melapor, diduga data yang dihasilkan berkemungkinan cenderung "underestimate”. Artinya, kejadian kriminalitas yang sesungguhnya diduga lebih besar dari yang dilaporkan. Dengan kata lain, angka gelap (dark number) kejahatan berkemungkinan masih relatif besar.

Data sekunder penelitian ini diperoleh melalui kajian literatur terhadap buku-buku, dokumendokumen, artikel dan lain sebagainya yang berkaitan dengan objek penelitian ini. Data sekunder yang diperoleh kemudian dianalisis guna menunjang data primer.

\section{Pengumpulan Data}

Pengumpulan data dilakukan untuk lima tahun terakhir, dan tahun berjalan. Pemilihan pengumpulan data sejak lima tahun terakhir dengan asumsi kondisi sosial masyarakat relatif belum jauh berbeda dengan kondisi saat ini. Hal ini guna melihat trend perkembangan dari tindak kejahatan yang ada. Data dikelompokkan berdasarkan kewilayahan tugas kepolisian (resort) yang 
ada di Pekanbaru, guna memetakan kota Pekanbaru berdasarkan tindak kejahatan yang terjadi.

Guna meminimalisir perbedaan pemaknaan terhadap tindak kriminal, penelitian ini dibatasi pada kejahatankejahatan tertentu yaitu: pembunuhan, pencurian dengan kekerasan (curas), pencurian dengan pemberatan (curat), perkosaan. Pemilihan jenis kejahatan ini karena merupakan kejahatan yang paling umum terjadi, dianggap serius, dan menjadi perhatian masyarakat secara umum, bahkan ketakutan akan kejahatan (fear of crime). Penelitian ini tidak membahas kejahatan-kejahatan yang tergolong dalam white collar crime seperti korupsi, pembakaran lahan dan hutan, ataupun cyber crime, kejahatankejahatan tersebut memiliki karakteristik dan analisis tersendiri.

\section{Teknik Pengumpulan Data}

Teknik pengumpulan data dalam penelitian ini meliputi tiga teknik; teknik observasi, teknik pencatatan data langsung, wawancara dan teknik dokumentasi. Teknik yang dominan digunakan dalam penelitian ini adalah teknik pencatatan data langsung, dan wawancara karena teknik ini dapat mengungkapkan gambaran yang terjadi pada inti permasalahan.

\section{Analisa Data}

Analisa data penelitian ini menggunakan cara statistik deskriptif. Data primer yang dikumpulkan berupa data berkala (time series data), yaitu data yang dikumpulkan dari waktu ke waktu guna mengetahui perkembangan (fluktuasi) kejahatan atau tindak kriminal yang dilaporkan/dicatat kepolisian. Data berkala umumnya tersaji dalam bentuk grafik garis (line chart) guna memudahkan pembuatan trend (Supranto, 2008: 40).

\section{Hasil Penelitian}

Penelitian ini difokuskan pada jumlah kejahatan yang dilaporkan dan tercatat pada kepolisian yang ada di wilayah hukum Pekanbaru guna memberi gambaran kondisi keamanan dan ketertiban Pekanbaru secara umum. Adapun parameter utama yang digunakan adalah: jumlah kejahatan tertentu yang dilaporkan (crime total), selang waktu terjadinya kejahatan (crime clock), dan risiko penduduk terkena kejahatan (crime rate).

1. Jumlah Kejahatan (Crime Total) dan Tren Kriminal

Selama kurun waktu 2012-2016, angka kejahatan yang terjadi dan dilaporkan di Kota Pekanbaru mengalami fluktuasi. Pada tahun 2012 
tercatat terjadi 901 kasus, menurun pada 2014 menjadi 791 kasus, kembali meningkat pada 2014 menjadi 928 kasus, kembali menurun pada tahun 2015 menjadi 897 kasus, dan mengalami sedikit peningkatan pada tahun 2016 menjadi 910 kasus. Secara lebih lengkap, jumlah kejahatan yang dilaporkan sejak 2012-2016 tersaji pada table 5.1:

Adapun tren kriminal Kota Pekanbaru untuk delapan tindak kriminal di atas tergambar pada grafik berikut:

\section{Gambar 5.1. Grafik Trend Kriminal}

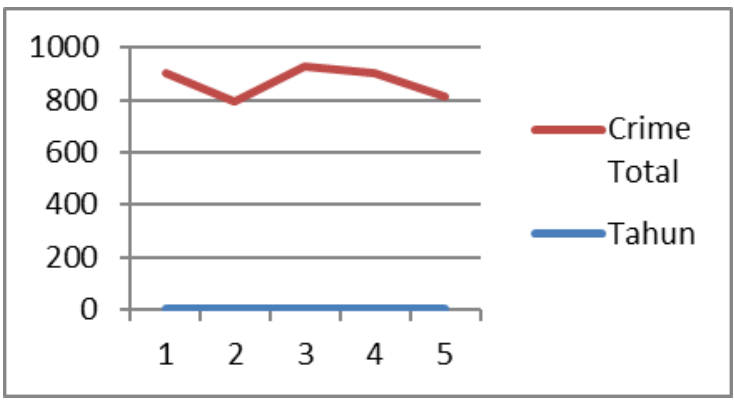

Pekanbaru Tahun 2012-2016

Sumber: Olah Data Penelitian

Grafik di atas menunjukkan adanya penurunan angka kejahatan pada tahun ke-2 (2013) dibanding tahun ke-1 (2012), dari 901 kasus menjadi 791 kasus. Meningkat di tahun ke-3 dan relative menurun pada tahun ke-4 dan ke-5. Secara umum angka kejahatan yang terjadi untuk delapan tindak pidana yang diteliti berkisar antara 800 hingga 900 kasus pertahunnya. Berdasarkan fluktuasi data kejahatan yang terjadi tersebut, dengan menjadikan tahun 2012 sebagai tahun awal perhitungan, maka dapat disusun persamaan linear trend kejahatan Kota Pekanbaru yaitu: $\mathrm{Y}=$ 835,25 + 19,5 X. Dimana X merupakan variable waktu, dan 19,5 merupakan rata-rata kenaikan atau penurunan tindak kriminal yang terjadi di Pekanbaru.

Persamaan linear tersebut dapat digunakan sebagai salah satu cara peramalan terhadap tindak kejahatan yang akan terjadi di kota Pekanbaru khusus untuk delapan jenis tindak kejahatan di atas, dengan data tahun 2012 sebagai data tahun awal. Misalnya ingin diketahui perkiraan angka kejahatan untuk delapan tindak kejahatan yang diteliti pada tahun 2020. Menggunakan persamaan tersebut diperoleh perkiraan pada tahun 2020 untuk delapan jenis kejahatan yang diteliti di Kota Pekanbaru terjadi 991 tindak kejahatan.

2. Indeks Kejahatan (Crime Index)

Fluktuasi atau naik turunnya angka kejahatan tergambar pada indeks kejahatan (indeks kriminal). Indeks kejahatan yaitu persentase kenaikan atau penurunan kejahatan selama setahun dibandingkan terhadap satu tahun tertentu (yang dijadikan tahun dasar). Semakin tinggi indeks kejahatan suatu wilayah mengindikasikan semakin 
rendahnya tingkat keamanan di masyarakat wilayah tersebut. Dengan membandingkan angka kejahatan tahun 2016 dengan angka kejahatan yang terjadi pada tahun 2012 (sebagai tahun acuan), diperoleh indeks kejahatan di kecamatan yang ada di Kota Pekanbaru adalah sebagai berikut:

Tabel 5.2.a. Indeks Kejahatan (Crime Indeks) menurut Polisi Sektor Tahun 2016 Dibanding Tahun 2012

\begin{tabular}{|c|c|c|c|}
\hline Polisi Sektor & \multicolumn{3}{|c|}{ Indeks Kejahatan } \\
\hline \multirow[t]{2}{*}{ Bukit Raya } & 213 & \multirow{2}{*}{$\times 100$} & \multirow{2}{*}{$=117.6796$} \\
\hline & 181 & & \\
\hline \multirow[t]{2}{*}{ Lima Puluh } & 46 & \multirow{2}{*}{$\times 100$} & \multirow{2}{*}{$=40$} \\
\hline & 115 & & \\
\hline \multirow{2}{*}{$\begin{array}{l}\text { Pekanbaru } \\
\text { Kota }\end{array}$} & 64 & \multirow{2}{*}{ X 100} & \multirow{2}{*}{$=110.3448$} \\
\hline & 58 & & \\
\hline \multirow[t]{2}{*}{ Rumbai } & 90 & \multirow{2}{*}{ X 100} & \multirow{2}{*}{$=140,625$} \\
\hline & 64 & & \\
\hline \multirow{2}{*}{$\begin{array}{l}\text { Rumbai } \\
\text { Pesisir }\end{array}$} & 33 & \multirow{2}{*}{ X 100} & \multirow{2}{*}{$=75$} \\
\hline & 44 & & \\
\hline \multirow[t]{2}{*}{ Senapelan } & 102 & \multirow{2}{*}{ X 100} & \multirow{2}{*}{$=96.22642$} \\
\hline & 106 & & \\
\hline \multirow[t]{2}{*}{ Sukajadi } & 122 & \multirow{2}{*}{ X 100} & \multirow{2}{*}{$=103.3898$} \\
\hline & 118 & & \\
\hline \multirow[t]{2}{*}{ Tampan } & 140 & \multirow{2}{*}{ X 100} & \multirow{2}{*}{$=65.11628$} \\
\hline & 215 & & \\
\hline \multirow[t]{2}{*}{ Pekanbaru } & 810 & \multirow{2}{*}{$\times 100$} & \multirow{2}{*}{$=89.90011$} \\
\hline & 901 & & \\
\hline
\end{tabular}

Sumber: Olah Data Penelitian

Fluktuasi atau naik turunnya kuantitas data angka kejahatan dapat dipengaruhi oleh banyak faktor, diantaranya seperti: terjadinya tindak pidana itu sendiri, konsentrasi atau kebijakan penanggulangan kejahatan oleh polisi, jumlah aparat kepolisian, frekuensi patroli atau razia, kecepatan penyelesaian kasus, pelaporan tindak pidana oleh masyarakat, dan lain sebagainya. Adapun kenaikan atau penurunan kejahatan yang terjadi di Pekanbaru tahun 2016 dibanding tahun 2012 tersaji pada table berikut:

Tabel 5.2.b. Perbandingan Angka Kejahatan menurut Polisi Sektor Tahun 2012-2016

\begin{tabular}{|l|c|c|c|}
\hline \multicolumn{1}{|c|}{ Polisi Sektor } & 2012 & 2016 & $\begin{array}{c}\text { Kenaikan atau } \\
\text { Penurunan (\%) }\end{array}$ \\
\hline Bukit Raya & 181 & 213 & -17.68 \\
\hline Lima Puluh & 115 & 46 & 60 \\
\hline Pekanbaru Kota & 58 & 64 & -10.34 \\
\hline Rumbai & 64 & 90 & -40.63 \\
\hline Rumbai Pesisir & 44 & 33 & 25 \\
\hline Senapelan & 106 & 102 & 3.77 \\
\hline Sukajadi & 118 & 122 & -3.39 \\
\hline Tampan & 215 & 140 & 34.88 \\
\hline Pekanbaru & 901 & 810 & 10.10 \\
\hline
\end{tabular}

Sumber: Olah Data Penelitian

Keterangan:

(-) menujukkan peningkatan

$(+)$ menunjukkan penurunan

Berdasarkan table 5.2 a dan b di atas tersaji peningkatan indeks kejahatan tertinggi Kota Pekanbaru selama kurun waktu lima tahun terjadi di Polsek Rumbai yakni sebesar $40 \%$ atau meningkat hampir satu setengah kali lipat dari tahun 2012 sebanyak 64 kasus menjadi 90 kasus di tahun 2016. Sedangkan penurunan indeks kejahatan 
terendah dicatat oleh Polsek Lima Puluh. Polsek Lima Puluh mencatat penurunan indeks kejahatan tahun 2016 dibanding tahun 2012 sebanyak 40\%. Dimana pada tahun 2012 tercatat 115 kasus, dan menurun menjadi 46 kasus pada tahun 2016. Sementara indeks kejahatan kota Pekanbaru secara keseluruhan tahun 2016 dibanding tahun 2012 mengalami penurunan lebih dari 10\% yakni dari 901 kasus di tahun 2012 menjadi 810 kasus di tahun 2016.

3. Waktu Terjadinya Kejahatan (Crime Clock)

Crime clock secara sederhana diartikan sebagai frekuensi terjadinya kriminalitas yang dinyatakan dalam selang waktu. Crime clock umumnya dihitung dalam satuan jam, manit, dan detik untuk kejahatan-kejahatan tertentu. Pada tabel 5.2 menunjukkan selang waktu terjadinya kejahatan pada tahun 2012 adalah 09.43'31" (9 jam 43 menit 31 detik), dan bertambah pada tahun 2013 menjadi 11.04'28" (11 jam 04 menit 28 detik). Kemudian pada tahun 2014 menurun menjadi 09.26'11" (9 jam 26 menit 11 detik), tahun 2015 meningkat menjadi 09.45'57" (9 jam 45 menit 57 detik), dan pada tahun 2016 menurun menjadi 10.48'53" (10 jam 48 menit 53 detik).
Interval waktu yang semakin panjang menunjukkan intensitas kejahatan yang semakin menurun. Dalam artian, semakin lama crime clock, maka semakin rendah atau menurunnya jumlah tindak kejahatan yang terjadi. Secara lebih lengkap, selang waktu terjadinya tujuh jenis kejahatan yang diteliti di kota Pekanbaru tersaji pada table 5.2.

4. Risiko Penduduk Terkena Kejahatan (Crime Rate)

Risiko penduduk Pekanbaru mengalami tindak kejahatan atau menjadi korban delapan jenis kejahatan yang dihitung pada penelitian ini terlihat pada table berikut:

Tabel 5.4. Risiko Penduduk Terkena Kejahatan (Crime Rate) menurut Polisi Sektor Tahun 2016

\begin{tabular}{|l|r|r|c|}
\hline \multicolumn{1}{|c|}{ Polisi Sektor } & $\mathbf{2 0 1 6}$ & $\begin{array}{c}\text { Jumlah } \\
\text { Penduduk* }\end{array}$ & $\begin{array}{c}\text { Crime } \\
\text { Rate }\end{array}$ \\
\hline Bukit Raya & 213 & 263.724 & 8,076621 \\
\hline Lima Puluh & 46 & 221.960 & 2,072443 \\
\hline Pekanbaru Kota & 64 & 27.390 & 23,36619 \\
\hline Rumbai & 90 & 76.765 & 11,72415 \\
\hline Rumbai Pesisir & 33 & 75.852 & 4,350583 \\
\hline Senapelan & 102 & 38.498 & 26,49513 \\
\hline Sukajadi & 122 & 153.085 & 7,969441 \\
\hline Tampan & 140 & 208.275 & 6,721897 \\
\hline Pekanbaru & $\mathbf{8 1 0}$ & 1.065 .548 & 7,601723 \\
\hline
\end{tabular}

Sumber: Olah Data Penelitian

* Perkiraan jumlah penduduk berdasarkan tingkat pertumbuhan penduduk per kecamatan di Pekanbaru. Sementara perkiraan pertumbuhan penduduk Kota Pekanbaru sekitar 2,6\% pertahun 
Table di atas menunjukkan risiko mengalami tindak kejahatan untuk delapan tindak kejahatan yang diteliti tertinggi pada wilayah hukum Polsek Senapelan, dimana dari tiap 10.000 orang penduduknya, sekitar 26 orang diantaranya berkemungkinan mengalami tindak kejahatan. Selanjutnya wilayah hukum Polsek Pekanbaru Kota tiap 10.000 orang penduduknya sekitar 23 orang mengalami tindak kejahatan. Sementara kemungkinan risiko terendah di wilayah hukum polsek Lima Puluh dimana dari setiap 10.000 orang penduduk, hanya dua orang diantaranya berisiko mengalami tindak kejahatan.

5. Pencurian Kendaraan Bermotor Roda

Dua (Curanmor R2)

Pencurian kendaraan bermotor roda 2 merupakan salah satu tindak kejahatan yang meresahkan masyarakat, mengingat kendaraan jenis ini masih merupakan kendaraan yang dimiliki oleh sebagian besar masyarakat di Pekanbaru.

Berdasarkan data diperoleh gambaran selama kurun waktu tahun 2012-2016 setidaknya terjadi 1278 kasus pencurian kendaraan roda dua yang dilaporkan kepada pihak kepolisian. Dalam kurun waktu lima tahun tersebut, data terbanyak di wilayah wilayah Polsek Bukit Raya sebanyak 300 kasus, selanjutnya Polsek Tampan sebanyak 246 kasus. Sementara Polsek Rumbai Pesisir mencatat angka pencurian kendaraan roda dua terendah, yaitu sebanyak 50 kasus.

\section{Pencurian dengan Pemberatan}

Pencurian dengan pemberatan juga merupakan jenis kejahatan yang memperoleh perhatian dari masyarakat. Selain pencurian, tindakan pencurian dengan pemberatan (curat) tidak jarang disertai dengan tindakan lainnya seperti perusakan, penganiayaan, perkosaan, bahkan pembunuhan. Hal inilah yang menyebabkan tindakan pencurian dengan memperoleh perhatian tersendiri dari masyarakat. Umumnya mereka yang telah mengalami peristiwa pencurian dengan pemberatan lebih merasa trauma dibanding mereka yang hanya mengalami pencurian biasa. Karena mereka yang pernah mengalami pencurian dengan pemberatan umumnya merasa berkemungkinan mengalami derita atau kerugian yang lebih besar dibanding kehilangan harta benda atau property mereka

Data yang diperoleh menunjukkan bahwa selama kurun 2012-2016, Polsek Bukit Raya mencatat peristiwa curat terbanyak di Pekanbaru yaitu sebanyak 296 kasus, dan disusul Polsek Senapelan 
sebanyak 131 kasus. Sementara Polsek Rumbai Pesisir mencatat peristiwa curat terendah dibanding Polsek lainnya yaitu sebanyak 34 kasus. Untuk wilayah hukum Polresta Pekanbaru tercatat sebanyak 1011 kasus curat selama kurun waktu 2012-2016. Secara keseluruhan, curat tertinggi terjadi pada tahun 2015 sebanyak 277 kasus, dan terendah terjadi pada tahun 2012 sebanyak 141 kasus.

\section{Penganiayaan}

Penaniayaan termasuk dalam jenis kejahatan kekerasan. Perkembangan kejahatan kekerasan dapat disebabkan oleh banyak faktor, bahkan dapat muncul sebagai hasil dari upaya represif dalam meminimalisir kekerasan itu sendiri. Kekerasan dalam hal ini penganiayaan dapat dilakukan oleh siapa saja, bahkan oleh aparat penegak hukum. Meski dalam komunitas tertentu kekerasan menjadi jalan alternative bagi penyelesaian permasalahan yang mereka hadapi.

Secara sederhana perkembangan kasus penganiayaan dicatat oleh polisi sektor yang ada Pekanbaru tahun 20122016 tergambar sebagai berikut:
Tabel 5.7. Penganiayaan menurut Polisi Sektor Tahun 20122016

\begin{tabular}{|l|r|r|r|r|r|r|}
\hline Polisi Sektor & 2012 & 2013 & 2014 & 2015 & 2016 & Jumlah \\
\hline Bukit Raya & 38 & 24 & 40 & 19 & 16 & 137 \\
\hline Lima Puluh & 43 & 39 & 32 & 17 & 4 & 135 \\
\hline $\begin{array}{l}\text { Pekanbaru } \\
\text { Kota }\end{array}$ & 9 & 12 & 13 & 9 & 9 & 52 \\
\hline Rumbai & 22 & 6 & 12 & 6 & 18 & 64 \\
\hline $\begin{array}{l}\text { Rumbai } \\
\text { Pesisir }\end{array}$ & 18 & 17 & 13 & 16 & 3 & 67 \\
\hline Senapelan & 20 & 9 & 8 & 18 & 25 & 80 \\
\hline Sukajadi & 19 & 18 & 20 & 20 & 8 & 85 \\
\hline Tampan & 49 & 22 & 25 & 11 & 18 & 125 \\
\hline Pekanbaru & 218 & 147 & 163 & 116 & 101 & 745 \\
\hline
\end{tabular}

Sumber: Olah Data Penelitian

Tabel di atas menunjukkan kurun waktu 2012-2016, Polisi Sektor Bukit Raya mencatat angka penganiaayan terbanyak yaitu 137 kasus, sedikit lebih banyak dibanding Polsek Lima Puluh sebanyak 135 kasus. Sementara angka penganiayaan terendah dicatat oleh Polsek Pekanbaru Kota sebanyak 52 kasus. Secara keseluruhan Pekanbaru, angka tertinggi dicatat pada tahun 2012 sebanyak 218 kasus, dan menurun drastis pada tahun 2016 menjadi 101 kasus.

8. Narkotika

Penyalahgunaan narkotika di Indonesia secara keseluruhan telah masuk pada wilayah memprihatinkan, sehingga kejahatan jenis ini digolongkan dalam extra ordinary crime atau kejahatan luar biasa. Kejahatan jenis ini umumnya tidak berdiri sendiri. Tidak 
jarang penyalahgunaan narkotika disertai dengan tindak kejahatan lainnya seperti pencurian, perampokan, perkosaan, dan lain sebagainya.

\section{Tabel 5.7. Penyalahgunaan Narkotika menurut Polsek Tahun 2012-2016}

\begin{tabular}{|l|r|r|r|r|r|r|}
\hline \multicolumn{1}{|c|}{$\begin{array}{c}\text { Polisi } \\
\text { Sektor }\end{array}$} & $\mathbf{2 0 1 2}$ & $\mathbf{2 0 1 3}$ & $\mathbf{2 0 1 4}$ & $\mathbf{2 0 1 5}$ & $\mathbf{2 0 1 6}$ & Jumlah \\
\hline Bukit Raya & 8 & 4 & 10 & 8 & 5 & 35 \\
\hline Lima Puluh & 0 & 0 & 0 & 0 & 0 & 0 \\
\hline $\begin{array}{l}\text { Pekanbaru } \\
\text { Kota }\end{array}$ & 5 & 4 & 1 & 6 & 13 & 29 \\
\hline Rumbai & 5 & 5 & 4 & 5 & 17 & 36 \\
\hline $\begin{array}{l}\text { Rumbai } \\
\text { Pesisir }\end{array}$ & 3 & 10 & 6 & 5 & 11 & 35 \\
\hline Senapelan & 17 & 24 & 10 & 10 & 18 & 79 \\
\hline Sukajadi & 5 & 3 & 0 & 2 & 3 & 13 \\
\hline Tampan & 1 & 6 & 2 & 5 & 15 & 29 \\
\hline Pekanbaru & 44 & 56 & 33 & 41 & 82 & 256 \\
\hline
\end{tabular}

Sumber: Olah Data Penelitian

Table di atas menggambarkan hampir seluruh wilayah Pekanbaru tidak ada yang terbebas dari penyalahgunaan narkotika, kecuali Polsek Lima Puluh yang belum pernah mencatat terjadinya penyalahgunaan narkotika selama kurun waktu lima tahun terakhir. Selama kurun waktu 2012-2016, kasus penyalahgunaan narkotika tertinggi dicatat oleh Polsek Senapelan yaitu sebanyak 79 kasus, disusul oleh Polsek Rumbai dan Rumbai Pesisir yaitu berturut-turut 36 dan 35 kasus.

\section{Penggelapan}

Penggelapan diartikan sebagai penyalahgunaan kepercayaan (one prestasion), dan umumnya mengarah pada kejahatan terhadap harta benda. Penggelapan diatur dalam pasal 372
KUHP. Perbuatan yang termasuk kategori ini adalah mengambil barang milik orang lain sebagian atau seluruhnya dimana penguasaan atas barang itu terjadi secara sah. Tujuan dari penggelapan adalah memiliki barang atau uang yang ada dalam penguasannya yang mana barang atau uang tersebut pada dasarnya adalah milik orang lain.

Selama kurun waktu lima tahun, Kepolisian Resort Kota Pekanbaru mencatat sebanyak 572 kasus penggelapan. Adapun gambaran tentang peristiwa penggelapan yang terjadi di Kota Pekanbaru tergambar pada table berikut:

Tabel 5.8. Penggelapan menurut Polisi Sektor Tahun 2012-2016

\begin{tabular}{|l|r|r|r|r|r|r|}
\hline Polisi Sektor & $\mathbf{2 0 1 2}$ & $\mathbf{2 0 1 3}$ & $\mathbf{2 0 1 4}$ & $\mathbf{2 0 1 5}$ & $\mathbf{2 0 1 6}$ & Jumlah \\
\hline Bukit Raya & 23 & 33 & 59 & 30 & 15 & 160 \\
\hline Lima Puluh & 19 & 26 & 30 & 24 & 11 & 110 \\
\hline $\begin{array}{l}\text { Pekanbaru } \\
\text { Kota }\end{array}$ & 9 & 16 & 27 & 11 & 8 & 71 \\
\hline Rumbai & 12 & 0 & 0 & 10 & 14 & 36 \\
\hline $\begin{array}{l}\text { Rumbai } \\
\text { Pesisir }\end{array}$ & 8 & 17 & 8 & 8 & 7 & 48 \\
\hline Senapelan & 10 & 4 & 7 & 15 & 11 & 47 \\
\hline Sukajadi & 17 & 12 & 8 & 17 & 13 & 67 \\
\hline Tampan & 10 & 7 & 6 & 7 & 3 & 33 \\
\hline Pekanbaru & 108 & 115 & 145 & 122 & 82 & 572 \\
\hline
\end{tabular}

Sumber: Olah Data Penelitian

10. Kekerasan Dalam Rumah Tangga

Kekerasan Dalam Rumah Tangga (KDRT) termasuk dalam kekerasan yang unik, dimana pelaku dan korban adalah orang yang seharusnya saling menyayangi. Fenomena KDRT ini menunjukkan bahwa kekerasan dapat dilakukan oleh siapa saja, kepada siapa saja, dan dimana saja, termasuk di dalam 
rumah yaitu suatu tempat yang seharusnya menjadi tempat yang paling aman bagi seseorang.

Selama tahun 2012-2017, tercatat 190 kasus KDRT di Pekanbaru, dimana Polsek Bukit Raya mencatat kasus KDRT terbanyak sebanyak 50 kasus, disusul Tampan sebanyak 49 kasus. Sementara Polsek Senapelan belum mencatat adanya kasus KDRT selama kurun waktu tersebut. Selama lima tahun tersebut, peristiwa KDRT tertinggi terjadi pada tahun 2012 sebanyak 53 kasus, dan terendah pada tahun 2015 sebanyak 27 kasus. Gambaran lebih lengkap tersaji pada table berikut.

\section{Tabel 5.9. Kekerasan Dalam Rumah Tangga menurut Polisi Sektor Tahun 2012-2016}

\begin{tabular}{|l|r|r|r|r|r|r|}
\hline \multicolumn{1}{|c|}{$\begin{array}{c}\text { Polisi } \\
\text { Sektor }\end{array}$} & 2012 & 2013 & 2014 & 2015 & 2016 & Jumlah \\
\hline Bukit Raya & 15 & 9 & 11 & 11 & 4 & 50 \\
\hline Lima Puluh & 7 & 15 & 6 & 2 & 4 & 34 \\
\hline $\begin{array}{l}\text { Pekanbaru } \\
\text { Kota }\end{array}$ & 3 & 3 & 1 & 1 & 0 & 8 \\
\hline Rumbai & 2 & 4 & 4 & 1 & 8 & 19 \\
\hline $\begin{array}{l}\text { Rumbai } \\
\text { Pesisir }\end{array}$ & 5 & 1 & 3 & 1 & 0 & 10 \\
\hline Senapelan & 0 & 0 & 0 & 0 & 0 & 0 \\
\hline Sukajadi & 7 & 5 & 4 & 0 & 4 & 20 \\
\hline Tampan & 14 & 7 & 11 & 10 & 7 & 49 \\
\hline Pekanbaru & 53 & 44 & 40 & 26 & 27 & 190 \\
\hline
\end{tabular}

Sumber: Olah Data Penelitian

11. Pencurian Kendaraan Bermotor Roda Empat

Pencurian kendaraan bermotor roda empat (curanmor r 4) termasuk kejahatan yang mengkhawatirkan masyarakat terutama bagi mereka pemilik kendaraan jenis tersebut. Gambaran angka peristiwa pencurian kendaraan roda empat yang terjadi selama tahun 2012-2016 tersaji pada table berikut:

\section{Tabel 5.10. Pencurian Kendaraan Bermotor Roda Empat menurut Polisi Sektor Tahun 2012-2016}

\begin{tabular}{|l|r|r|r|r|r|r|}
\hline \multicolumn{1}{|c|}{$\begin{array}{c}\text { Polisi } \\
\text { Sektor }\end{array}$} & 2012 & 2013 & 2014 & 2015 & 2016 & Jumlah \\
\hline Bukit Raya & 5 & 8 & 1 & 1 & 5 & 20 \\
\hline Lima Puluh & 0 & 0 & 0 & 0 & 0 & 0 \\
\hline $\begin{array}{l}\text { Pekanbaru } \\
\text { Kota }\end{array}$ & 0 & 0 & 1 & 2 & 2 & 5 \\
\hline Rumbai & 0 & 0 & 1 & 1 & 0 & 2 \\
\hline $\begin{array}{l}\text { Rumbai } \\
\text { Pesisir }\end{array}$ & 0 & 1 & 1 & 0 & 0 & 2 \\
\hline Senapelan & 0 & 1 & 1 & 2 & 0 & 4 \\
\hline Sukajadi & 1 & 0 & 1 & 0 & 2 & 4 \\
\hline Tampan & 17 & 8 & 0 & 12 & 11 & 48 \\
\hline Pekanbaru & 23 & 18 & 6 & 18 & 20 & 85 \\
\hline
\end{tabular}

Sumber: Olah Data Penelitian

Pada table tersebut di atas tergambar selama tahun 2012 hingga 2016, Polsek Tampan mencatat angka peristiwa tertinggi yaitu sebanyak 48 kasus, hampir setengah dari peristiwa pencurian kendaraan roda empat yang ada di Pekanbaru sebanyak 85 kasus. Posisi kedua tertinggi ditempati oleh Polsek Bukit Raya yang mencatat 20 kasus. Sementara Polsek Lima Puluh belum ada mencatat peristiwa pencurian curanmor roda empat. Dalam kurun waktu 20122016, kasus curanmor r 4 tertinggi terjadi tahun 2012 sebanyak 23 kasus, dan terendah terjadi pada tahun 2014 yaitu sebanyak 6 kasus. 
12. Jambret

Jambret diidentikkan sebagai kejahatan jalanan, karena umumnya terjadi di area umum atau jalanan, mulai dari tempat sepi, hingga di keramaian. Meski jambret sering dikelompokkan sebagai kejahatan kelas ringan atau kelas “teri”, namun maraknya aksi penjambretan tetap menarik perhatian masyarakat, dan mendatangkan kekhawatiran tersendiri terutama bagi mereka yang merasa rentan menjadi korban perbuatan tersebut.

Pada table berikut tergambar angka peristiwa jambret yang pernah terjadi di Pekanbaru.

Tabel 5.11. Angka Penjambretan menurut Polisi Sektor Tahun 2012-2016

\begin{tabular}{|l|c|c|c|c|c|c|}
\hline \multicolumn{1}{|c|}{$\begin{array}{c}\text { Polisi } \\
\text { Sektor }\end{array}$} & $\mathbf{2 0 1 2}$ & $\mathbf{2 0 1 3}$ & $\mathbf{2 0 1 4}$ & $\mathbf{2 0 1 5}$ & $\mathbf{2 0 1 6}$ & Jumlah \\
\hline Bukit Raya & 0 & 0 & 10 & 12 & 32 & 54 \\
\hline Lima Puluh & 0 & 0 & 0 & 0 & 0 & 0 \\
\hline $\begin{array}{l}\text { Pekanbaru } \\
\text { Kota }\end{array}$ & 0 & 0 & 10 & 2 & 0 & 12 \\
\hline Rumbai & 0 & 0 & 0 & 0 & 0 & 0 \\
\hline $\begin{array}{l}\text { Rumbai } \\
\text { Pesisir }\end{array}$ & 5 & 1 & 0 & 0 & 1 & 7 \\
\hline Senapelan & 0 & 0 & 0 & 0 & 0 & 0 \\
\hline Sukajadi & 19 & 6 & 0 & 0 & 18 & 43 \\
\hline Tampan & 22 & 19 & 7 & 19 & 7 & 74 \\
\hline Pekanbaru & 46 & 26 & 27 & 33 & 58 & 190 \\
\hline
\end{tabular}

Sumber: Olah Data Penelitian

\section{A. Pembahasan}

Gambaran dasar dari trend kejahatan di Pekanbaru dalam kurun waktu lima tahun ini menunjukkan gejala fluktuasi, dimana untuk tahun 2014 hingga 2016 seakan mengalami pelambatan dibanding tahun 2012 dan 2013. Kesan adanya pelambatan ini dimungkinkan karena adanya lembaga ad hoc yang juga menangani permasalahan-permasalahan tertentu seperti Badan Narkotika Nasional Provinsi Riau terkait penyalahgunaan narkotika, Pusat Pelayanan Terpadu Perlindungan Perempuan dan Anak (P2TP2A) yang menangani tindak kekerasan dalam rumah tangga, termasuk kekerasan terhadap anak, dan lain sebagainya. Keberadaan lembaga-lembaga ini memungkinkan tidak semua peristiwa yang terjadi tercatat dalam catatan kepolisian.

Bila dilihat dari penyebaran peristiwa kejahatan, wilayah Polsek Bukit Raya merupakan wilayah yang mencatat gangguan keamanan tertinggi bila dibanding wilayah hukum polsek lainnya yang ada di Pekanbaru. Dalam kurun waktu 2012-2016, Polisi Sektor Bukit Raya mencatat telah terjadi 1052 kasus, hampir seperempat dari total tindak pidana yang tercatat di Pekanbaru yaitu 4327 kasus. Artinya dari sepuluh kejadian tindak kejahatan yang diteliti, empat diantaranya terjadi di wilayah hukum Polsek Bukit Raya. 
Wilayah tertinggi kedua gangguan keamanan dan ketertiban selanjutnya adalah wilayah hukum Polisi Sektor Tampan. Dimana dalam kurun waktu tersebut mencatat angka 710 kasus. Adapun wilayah yang memiliki gangguang keamanan dan ketertiban terendah adalah Polisi Sektor Rumbai Pesisir sebanyak 253 kasus.

Polisi Sektor Bukit Raya mendominasi hampir semua tindak kejahatan yang diteliti dalam penelitian ini, kecuali penyalahgunaan narkotika, pencurian kendaraan bermotor roda empat (curanmor r 4), dan penjambretan. Dimana untuk penyalahgunaan narkotika tertinggi tercatat di Polsek Senapelan. Sedangkan tindak curanmor $\mathrm{r}$ 4, dan jambret tertinggi dicatat oleh Polsek Tampan.

Berdasarkan penjelasan di atas tergambar peta rawan kejahatan di Pekanbaru. Bila kita menempatkan daerah tertinggi gangguan keamanan dan ketertiban sebagai zona merah, maka wilayah hukum Polsek Bukit Raya dan Polsek Tampan sebagai wilayah merah gangguan keamanan dan ketertiban di Pekanbaru pada penelitian ini. Sehingga dapat disusun kebijakan kriminal tersendiri bagi kedua wilayah tersebut. Misalnya, untuk wilayah hukum Polsek
Tampan yang memiliki banyak jalan alternatif, dan beberapa bagian wilayah atau jalannya mengarah ke daerah yang masih jarang penduduknya. Untuk itu, mungkin dapat diperbanyak personil reaksi cepat guna mengantisipasi pergerakan curanmor roda empat, atau penjambretan yang memiliki pola khas hit and run, dan mengandalkan kegesitan guna melarikan diri.

\section{Kesimpulan}

Berdasarkan data statistik kriminal kepolisian di wilayah hukum polisi sektor yang ada di Pekanbaru selama kurun waktu 2012-2016 dalam penelitian ini dapat disimpulkan bahwa:

1. Puncak total kejahatan (crime total) dicapai pada tahun 2014 sebanyak 928 kasus, dan relatif mengalami penurunan untuk tahun-tahun berikutnya. Total angka kejahatan mengalami fluktuasi dengan menunjukkan tren peningkatan atau penurunan sebesar 19,5 kasus per tahun.

2. Berdasarkan crime rate, penduduk di wilayah hukum Polsek Senapelan memiliki potensi tertinggi mengalami kejahatan, yaitu dari 10.000 penduduk, 26 diantaranya mungkin mengalami kejahatan. 
3. Selama kurun waktu 2012-2016, Polsek Bukit Raya mencatat angka kejahatan tertinggi sebanyak 1052 kasus, disusul Polsek Tampan sebanyak 710 kasus. Adapun angka kejahatan terendah dicatat oleh Polsek Rumbai Pesisir sebanyak 253 kasus.

4. Polisi Sektor Bukit Raya mendominasi hampir semua tindak kejahatan yang diteliti dalam penelitian ini, kecuali penyalahgunaan narkotika, pencurian kendaraan bermotor roda empat (curanmor $r$ 4), dan penjambretan. Dimana untuk penyalahgunaan narkotika tertinggi tercatat di Polsek Senapelan. Sedangkan tindak curanmor $\mathrm{r}$ 4, dan jambret tertinggi dicatat oleh Polsek Tampan.

\section{Saran}

Berdasarkan hasil analisa penelitian, dapat penulis sarankan:

1. Kepada pamangku kebijakan: agar dapat memperioritaskan kebijakan kriminal (criminal policing) sesuai dengan kebutuhan dan karakteristik wilayah yang ada.

2. Aparat Penegak Hukum: agar lebih peka terhadap perubahan dinamika sosial yang ada di

tengah masyarakat, dan konsisten dalam pelaksanaan prosedur operasional standar, mulai dari pencatatan hingga penanganan laporan.

3. Kepada masyarakat agar lebih peduli terhadap lingkungan sekitar mereka, mau dan mampu melaporkan semua peristiwa kejahatan yang mereka alami kepada pihak kepolisian atau pihak terkait. Penelitian lanjutan dengan penyertaan pendekatan kualitatif, dan menambahkan faktor lain seperti: laju urbanisasi, kondisi ekonomi lokal maupun nasional, persepsi masyarakat tentang kejahatan, dan lain sebagainya, dapat dilakukan guna memperoleh gambaran lebih jelas tentang wajah kejahatan dipekanbaru.

\section{Daftar Pustaka}

Badan Pusat Statistik, 2015. Statistik Kriminal 2015. Jakarta

Badan Pusat Statistik Kota Pekanbaru, 2016. Kecamatan Bukit Raya Dalam Angka 2016. Badan Pusat Statistik Pekanbaru.

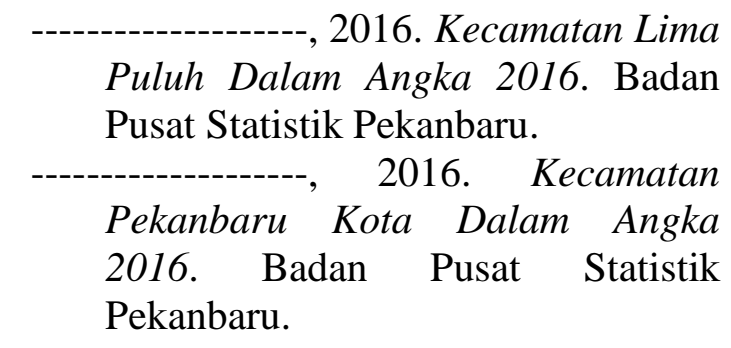


2016. Kecamatan

Rumbai Dalam Angka 2016. Badan Pusat Statistik Pekanbaru.

2016. Kecamatan

Rumbai Pesisir Dalam Angka 2016.

Badan Pusat Statistik Pekanbaru.

------------------, 2016. Kecamatan

Senapelan Dalam Angka 2016.

Badan Pusat Statistik Pekanbaru.

2016. Kecamatan

Sukajadi Dalam Angka 2016. Badan

Pusat Statistik Pekanbaru.

----------------, 2016. Kecamatan

Tampan Dalam Angka 2016. Badan

Pusat Statistik Pekanbaru.

Darmawan, M. Kemal, 2007. Teori Kriminologi. Jakarta: Penerbit Universitas Terbuka.

Goldberger, Arthur S., Richard Rosenfeld (Editors), 2008. Understanding Crime Trends: Workshop Report Committee on Understanding Crime Trends. Washington, DC: The National Academies Press.

Kartono, Kartini., 1988. Patologi Sosial Jilid 1 Edisi Baru. Jakarta: Rajawali Press.

Kusumah, Mulyana W. 1982. Analisa Kriminologi tentang KejahatanKejahatan Kekerasan. Jakarta: Ghalia Indonesia.

Mustofa, $\quad 2010$. Kriminologi, Kajian Sosiologi Terhadap Kriminalitas, Perilaku Menyimpang dan Pelanggaran Hukum. Bekasi: Sari Ilmu Pratama.

Santoso, Topo., dan Zulfa, Eva Achjani, 2011. Kriminologi. Jakarta: Rajawali Perss.

Schneider, Richard H. and Ted Kitchen. 2004. Planning For Crime Prevention A TransAtlantic Perspective.London and New York: Routledge Taylor and Francis Group.
Supranto, J. 2008. Statistic Teori dan Aplikasi Jilid 1. Jakarta: Penerbit Erlangga 